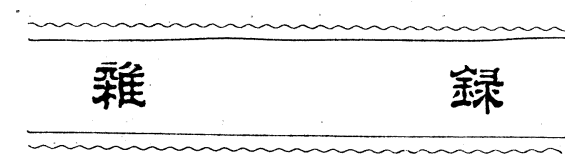

\title{
黨業製品の輸入狀況
}

\section{小林 作 平}

財界不況對策、經濟國難打開策、金解禁對策等々の䉆め官民共に力在畫して居るものに座業の 合理化運動及國產品愛用の運動がある。

座業の合理化に就ては䇺業界でも考へねばなら業種は澤山する。大に業界各位の意見の發表 を見、賽行運動の實現に邁進せられんてとを希残する。國產愛用の運動に連れて必要なのは如何 なるものが輸入されて居るかである、筧業品は幸に輸入老防遏した種類で今日此比ての種運動に

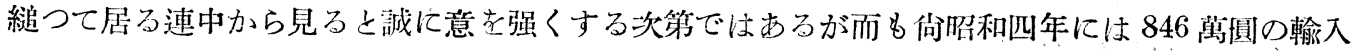

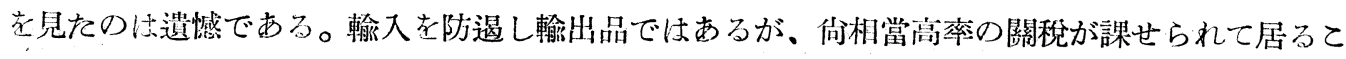
とは一考在要することである。

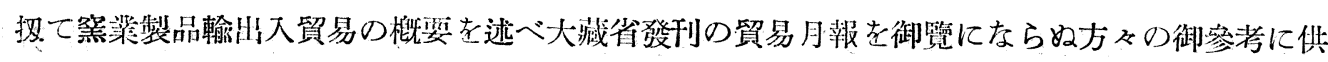

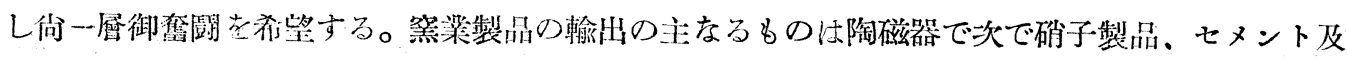

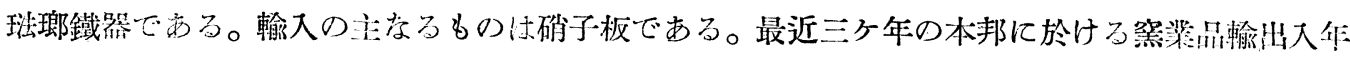
額第一及第二表の通りである。

\section{第一表 箘業品輸出額（單位千圆）}

\begin{tabular}{|c|c|c|c|c|c|}
\hline \multirow{2}{*}{\multicolumn{2}{|c|}{ 種 }} & \multicolumn{2}{|c|}{ 年 } & 次 & \multirow[b]{3}{*}{ 三及四年は玩具吉含屯 } \\
\hline & & 昭和二年 & 佋和三年 & 昭和四年 & \\
\hline 陶 & 磁 & 30,491 & 35,033 & 37,368 & \\
\hline 确二 & 级硙子製品 & 18,508 & 17,763 & 18,011 & 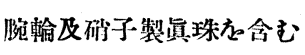 \\
\hline t & ン & 7,122 & 6,885 & 9,182 & \\
\hline 班 & 理 鐵 & 5,933 & 6,144 & 6,707 & \\
\hline & 計 & 62,054 & 66,125 & 71,268 & \\
\hline
\end{tabular}

即昨年は7.120 餘灌圓の輸出老なし大體に於て發展の種頑に見えるのは喜ぶへき現像である。 第二表：窯業品輸大額 (單位千回)

\begin{tabular}{llll}
\multicolumn{2}{c}{ 種 } & \multicolumn{2}{c}{ 類 } \\
确 & 板 & 類 \\
的 & 火 煉 & 瓦
\end{tabular}

其他の确子及粘土製品

\begin{tabular}{ccc}
\multicolumn{2}{c}{ 年 } & \multicolumn{2}{c}{ 次 } \\
\hline 昭和二年 & 昭和三年 & 昭和四年 \\
5,600 & 6,712 & 6,145 \\
329 & 1.062 & 561 \\
746 & 1,042 & 946
\end{tabular}




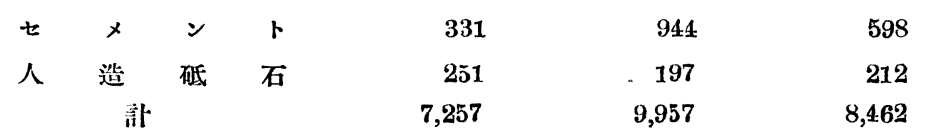

郎昨年の輸入は 846 萬圆である美引輸出超過は 6.280 萬圓である。此の外に䈍業に關係深い原 料の輸入が相當あるが今旬は省略する。㧋て次に吾くが知らんと欲するものは輸入品の種颣及そ の輸入先でするが今前推輸入表の各項目について更に詳細に解剖して見ると次表の樣を結果とな る。

\section{第三表 确子板類輸入額 (單位于[国)}

(1) 無色平面厚 $2.2 \mathrm{~mm}$ 以下

\begin{tabular}{|c|c|c|}
\hline 國 & & 名 \\
\hline 支 & & 那 \\
\hline 關 & 東 & 州 \\
\hline 英 & 吉 & 利 \\
\hline 佛 & 閶 & 西 \\
\hline 獨 & & 逸 \\
\hline 白 & 耳 & 清 \\
\hline
\end{tabular}

湖

(2) 省色平面原 $4 \mathrm{~mm}$ 以下

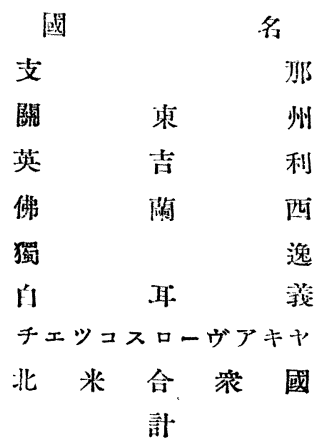

（3）無色平面（其の他）

\begin{tabular}{|c|c|c|}
\hline 國 & & 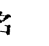 \\
\hline 支 & & 那 \\
\hline 關 & 東 & 州 \\
\hline 英 & 吉 & 利 \\
\hline 佛 & 閵 & 晒 \\
\hline 獨 & & 逸 \\
\hline 白 & 耳 & 䉝 \\
\hline 伊 & 太 & 利 \\
\hline
\end{tabular}

\begin{tabular}{|c|c|c|}
\hline \multicolumn{2}{|c|}{ 年: } & \\
\hline 㕷犁二年 & 昭和三年 & 炤和四 \\
\hline 128 & - & - \\
\hline 561 & 289 & 413 \\
\hline 5 & - & 5 \\
\hline - & 2 & 1 \\
\hline 3 & 9 & $3 \pm$ \\
\hline 320 & 510 & 442 \\
\hline - & - & 5 \\
\hline 1,019 & 812 & 886 \\
\hline
\end{tabular}

\begin{tabular}{|c|c|c|}
\hline \multicolumn{2}{|c|}{ 年 } & \\
\hline 佲和二住 & 沼和三年 & 炤和四任 \\
\hline 160 & 234 & 73 \\
\hline 35 & 4 & - \\
\hline 4 & 13 & 20 \\
\hline- & 11 & 9 \\
\hline 25 & 40 & 66 \\
\hline 158 & 117 & 125 \\
\hline 1 & $\cdot 3$ & 12 \\
\hline 3 & 13 & 16 \\
\hline 394 & 438 & 323 \\
\hline
\end{tabular}




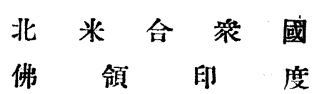
ifi

4）其他の硝子·板類

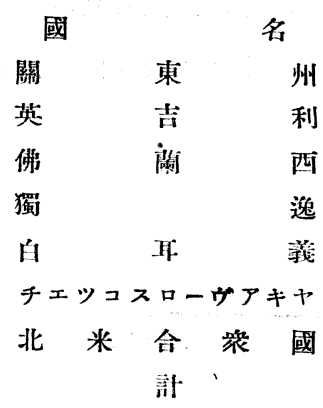

（5）金屬線又は網入の确子板

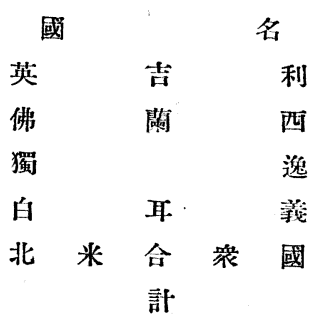

$\begin{array}{rrr}83 & 197 & 38 \\ - & - & 2 \\ 2,916 & 3,250 & 3,175\end{array}$

\begin{tabular}{ccc}
\multicolumn{2}{c}{ 年 } & \multicolumn{2}{c}{ 次 } \\
昭和二年 & 昭和三年 & 昭和四年 \\
57 & 168 & 105 \\
42 & 71 & 49 \\
47 & 69 & 211 \\
15 & 88 & 74 \\
590 & 949 & 743 \\
- & 3 & 8 \\
65 & 49 & 70 \\
818 & 1,397 & 1,260
\end{tabular}

第四表 板類以外の硝子及硝子製品輸入額（單位[回）

昭和三年

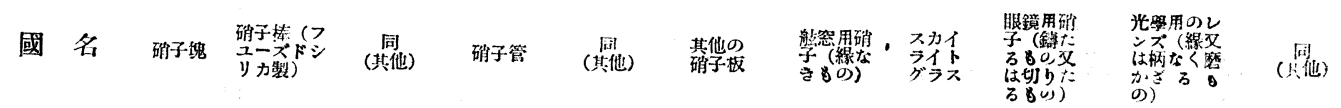

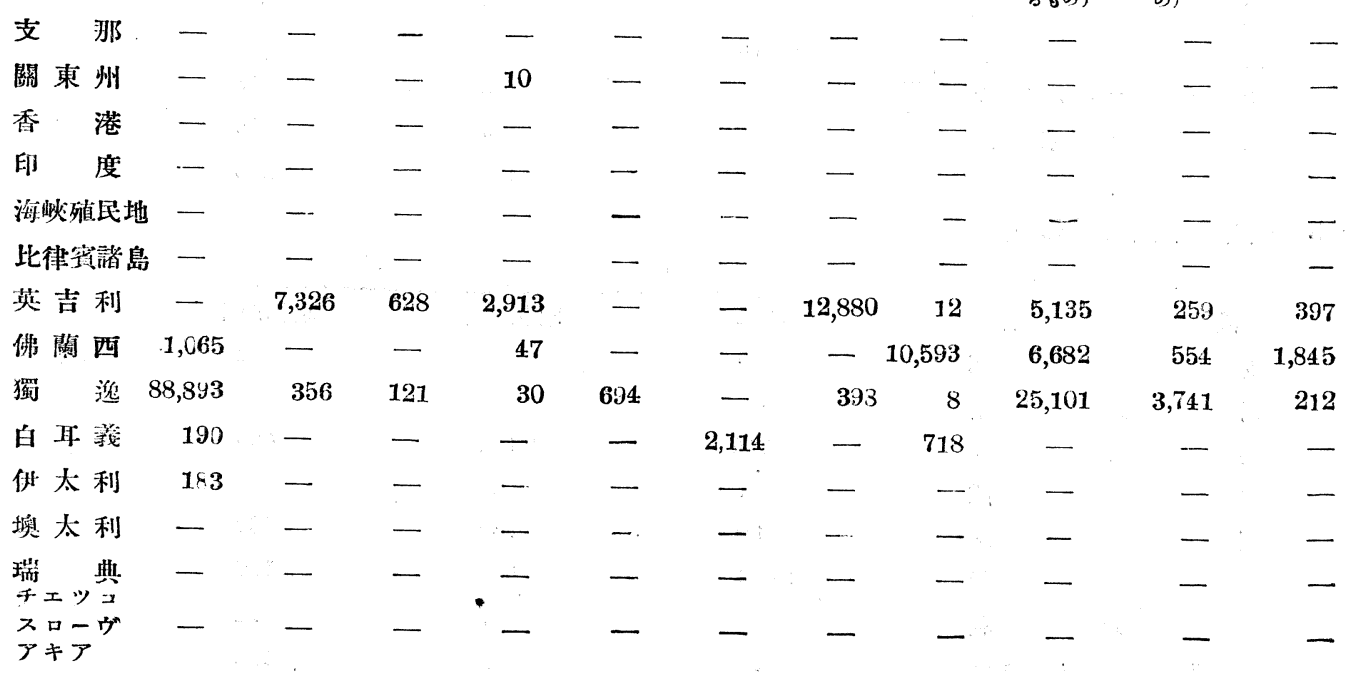




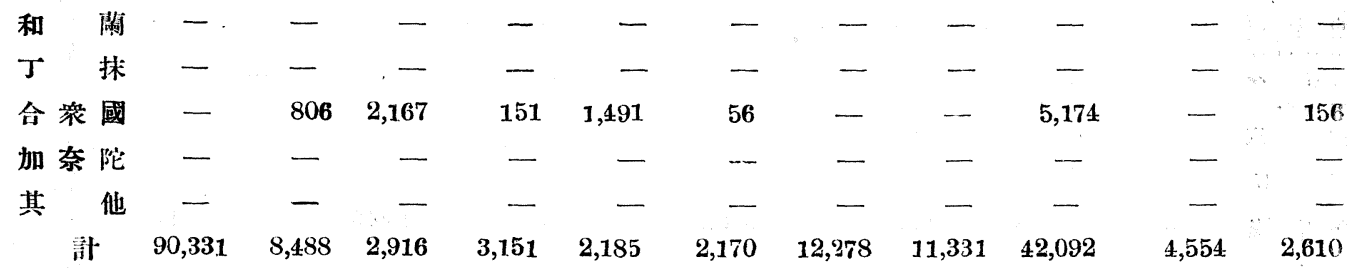

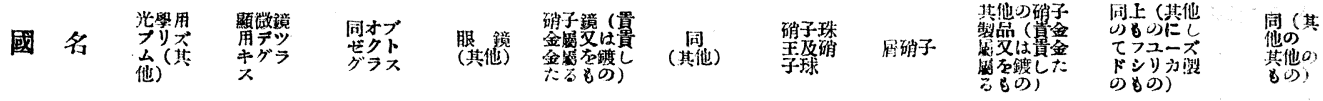
支 那 關東州 - - - - - - 香 港 - - - - - - - - - - - 印度 - - - - $-1-\cdots$ 海峽殖民地 一 - - - - - - - - - - - 比律瀆諸島

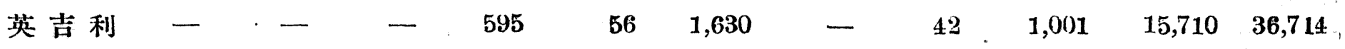

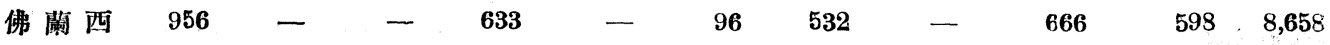

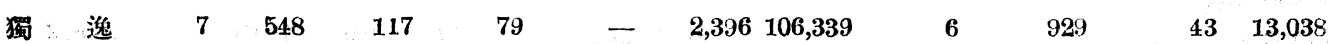

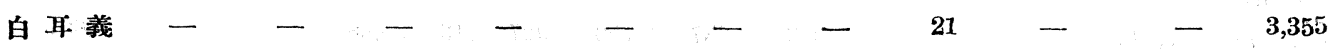
伊太利 墺太利 瑞 典 — - $\quad$ - 313 - 3 -

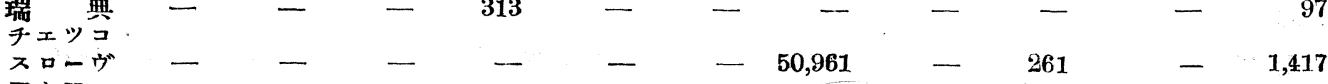

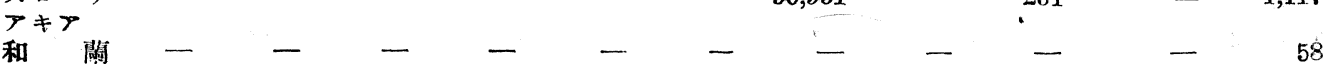
丁 抹 一

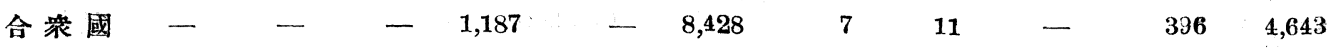
加奈陀 一 - - - - - 其 他 $\begin{array}{llllllllllll}\text { 部 } & 963 & 548 & 117 & 2,807 & - & 12,772 & 166,194 & 291 & 2,866 & 16,747 & 70,105\end{array}$ 昭 和四年

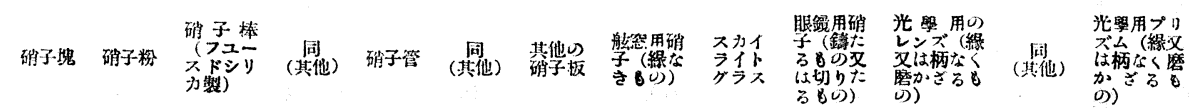
支 那 - - - - - - - - - - - 關東州 - - - - -2 - 2 - -30 印度 - - - - $-\cdots-1-$ 闌領印度 - - - - - - - - - - - 英吉利 $610 \quad-\quad 7,326-13,762 \quad 129 \quad-\quad 5,760 \quad 2,280 \quad 9 \quad-234-$

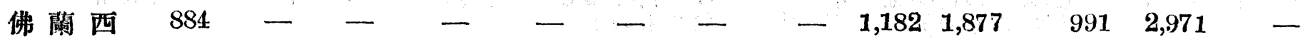

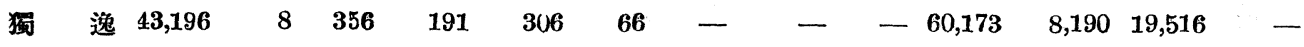
白耳莪 1,720 - - - -114 - $4,459-749-438$ 伊太利 - - - - - - - - - - - - - 瑞 典 - - - - -2 - - - 


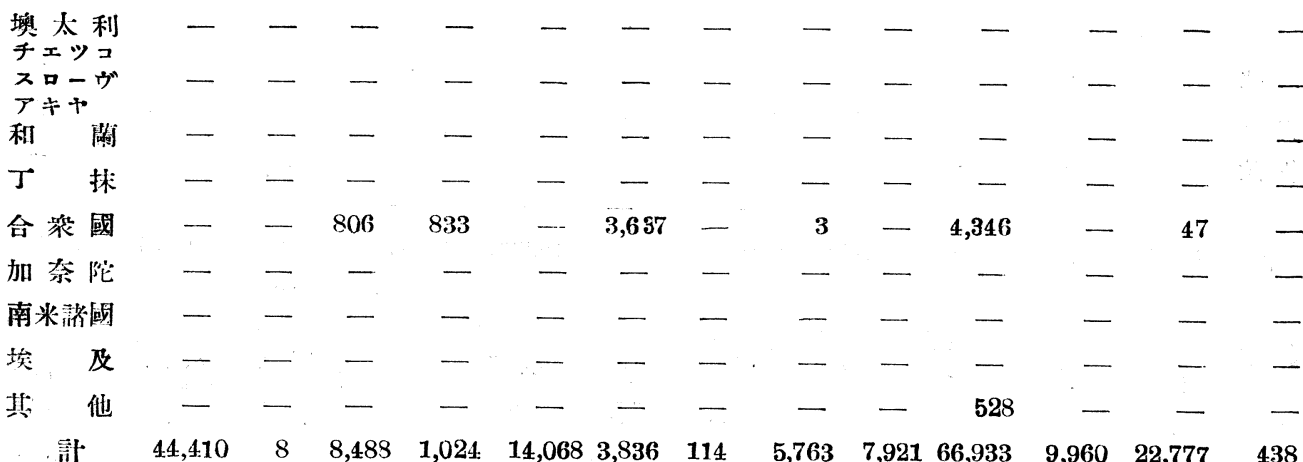

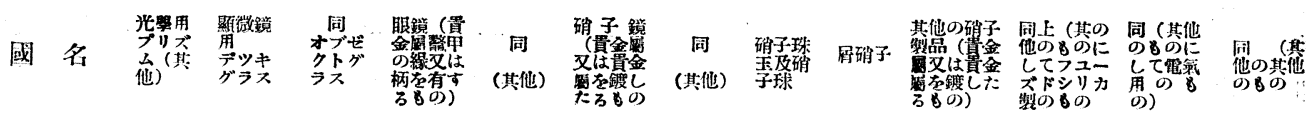

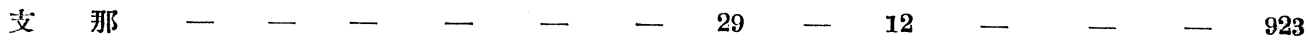

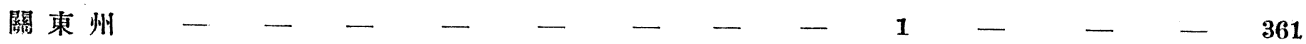

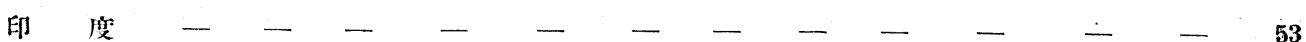

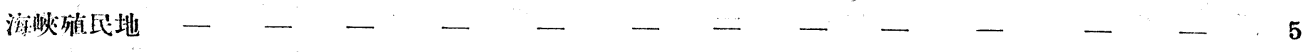

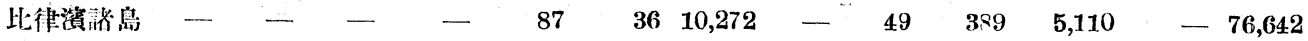

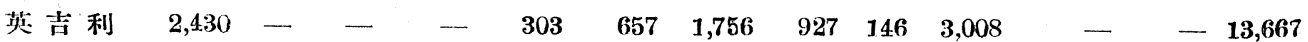

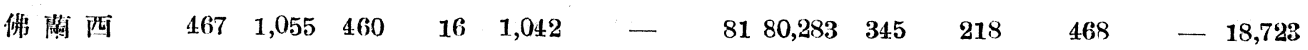

$$
\begin{aligned}
& \text { 獨 逸 - } \\
& \text { 日耳笔 }
\end{aligned}
$$

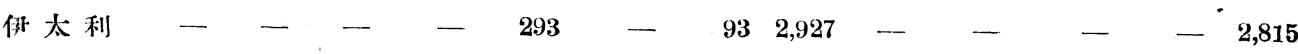

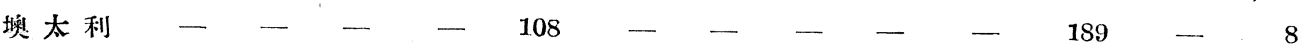

$$
\begin{aligned}
& \begin{array}{llllllllllllll}
\text { 瑞ェッ典 } & - & - & - & - & - & - & 27 & - & - & - & - & - & 1
\end{array}
\end{aligned}
$$

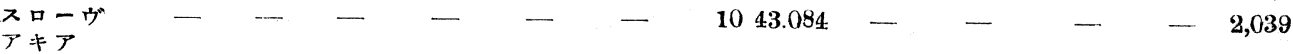

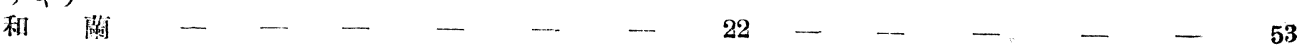

$$
\begin{aligned}
& \text { 丁 捄 一 - - - - - - - - - - - - - } 10
\end{aligned}
$$

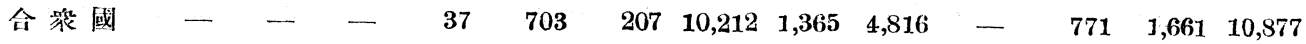

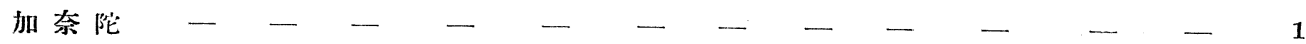

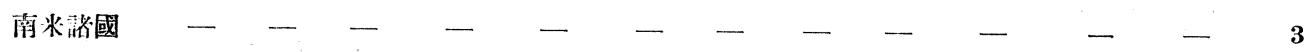

$$
\begin{aligned}
& \text { 埃 及 - - - - - - - - - - - - - - } 24
\end{aligned}
$$

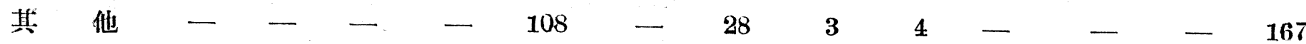

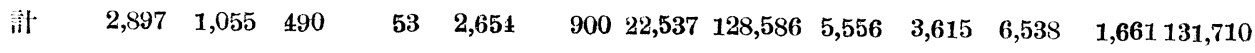

$$
\begin{aligned}
& \text { 笨五表 粘土製品耐火物陶器及瓦等輸入額 (單位圓) }
\end{aligned}
$$

昭和三年

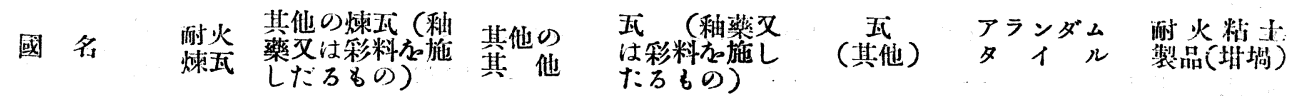

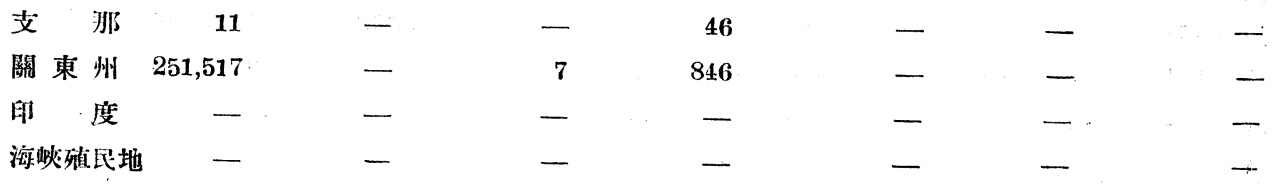




\begin{tabular}{|c|c|c|c|c|c|c|c|}
\hline \multirow{2}{*}{$\begin{array}{l}\text { 满領印度 } \\
\text { 伤領印度 }\end{array}$} & - & - & - & - & - & - & - \\
\hline & - & - & - & - & - & - & - \\
\hline 比津宾嘴島 & - & - & - & - & - & - & - \\
\hline 英 吉 利 & 98,708 & - & 18,647 & - & - & - & - \\
\hline 佛 蘭 西 & - & - & - & - & - & - & - \\
\hline \multirow{2}{*}{ 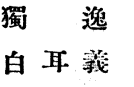 } & 508,059 & - & 11,509 & 2 & 1,235 & - & 371 \\
\hline & - & - & - & - & - & - & - \\
\hline 倔太利 & 15 & - & - & 4 & - & - & - \\
\hline \multirow{2}{*}{$\begin{array}{l}\text { 堸太利 } \\
\text { チエツコス } \\
\text { ロヴアキャ }\end{array}$} & 14,228 & - & - & - & - & - & - \\
\hline & - & - & - & - & - & - & - \\
\hline 和＼cjkstart闌 & - & - & - & - & - & 一 & - \\
\hline 瑞 典 & $1, \pm 01$ & - & - & - & - & - & - \\
\hline 諾＼cjkstart威 & - & - & - & - & - & - & - \\
\hline 露西琶 & - & - & - & - & - & - & - \\
\hline 西班牙 & - & - & - & $r^{\prime} 4$ & - & - & - \\
\hline \multirow{2}{*}{$\begin{array}{lr}\text { 丁 珠 } \\
\text { 合乑國 }\end{array}$} & - & - & - & - & - & - & - \\
\hline & 196,173 & 63 & 1,445 & 394,475 & 3,041 & 5,737 & 201 \\
\hline 加奈陀 & 2,419 & - & - & - & - & - & - \\
\hline 伯刺西爾 & - & - & - & - & - & - & - \\
\hline \multirow{2}{*}{ 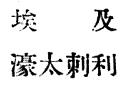 } & - & - & - & - & - & - & - \\
\hline & - & - & - & - & - & - & - \\
\hline 其＼cjkstart他 & 400 & - & - & - & - & - & - \\
\hline 部 & $1,062.931$ & 63 & 31,608 & 395,437 & 4,276 & 5,737 & 572 \\
\hline
\end{tabular}

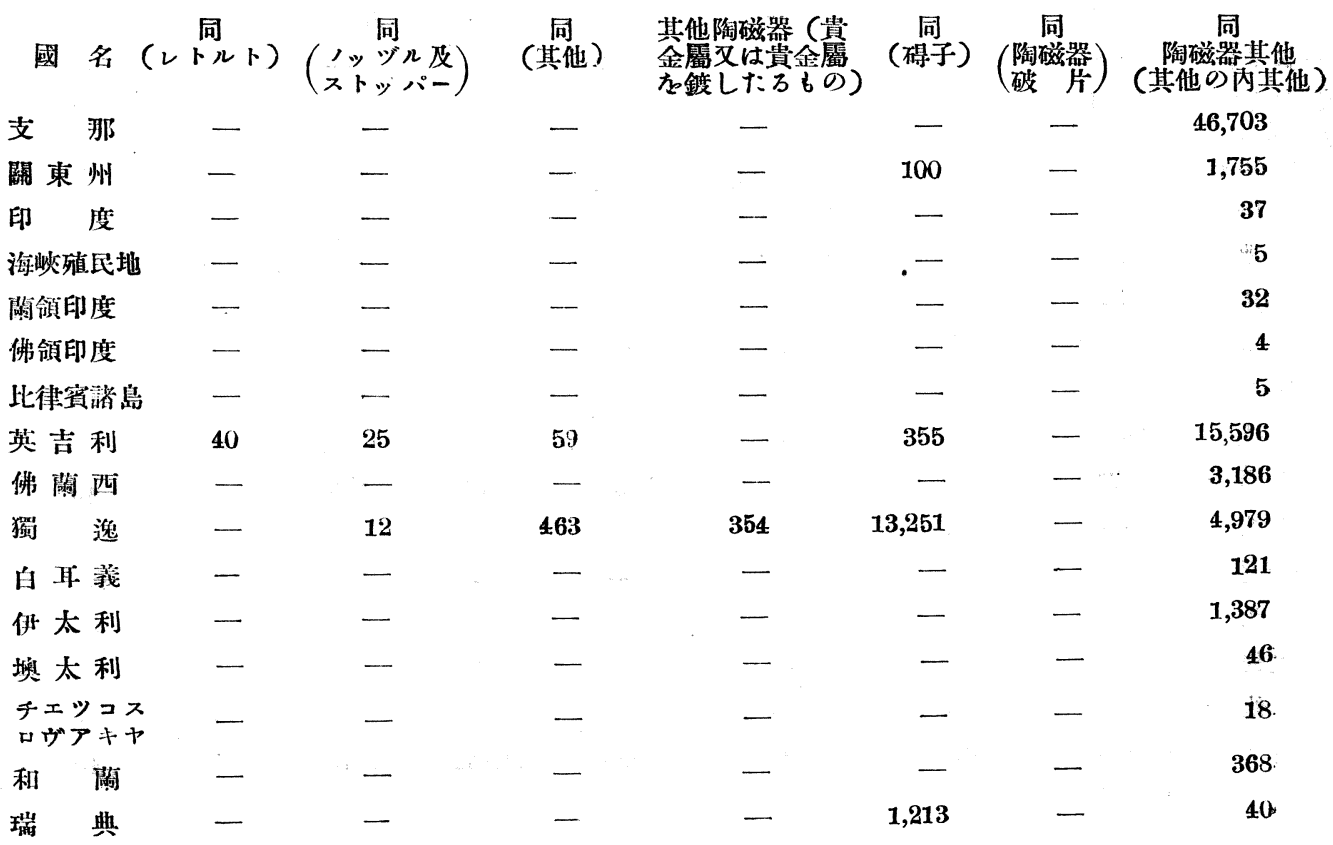




\begin{tabular}{|c|c|c|c|c|c|c|c|}
\hline 諾 威 & - & - & - & - & - & - & 15 \\
\hline 露 西 亞 & - & - & - & - & - & - & 10 \\
\hline 西 班 牙 & - & - & - & - & - & - & 111 \\
\hline 丁 珠 & - & - & - & - & - & - & 4,595 \\
\hline 合 裳 國 & 44 & - & 6,455 & - & 10,752 & - & 33,020 \\
\hline 加奈陀 & - & - & - & - & - & - & 123 \\
\hline 伯刺西爾 & - & - & - & - & - & - & 69 \\
\hline 埃 及 & - & - & - & - & - & - & 38 \\
\hline 碇太刺利 & $\cdot-$ & - & - & - & - & - & 1 \\
\hline 其 他 & - & - & - & - & - & 128 & 69 \\
\hline 部 & 84 & 37 & 6,977 & 354 & 25,671 & 128 & 112,283 \\
\hline
\end{tabular}

昭和四年

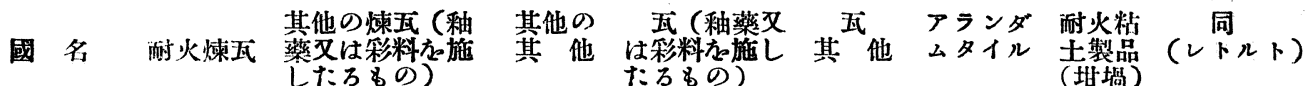

\begin{tabular}{|c|c|c|c|c|c|c|c|c|}
\hline 那 & - & - & - & 355 & 32 & 32 & - & - \\
\hline 關 東 州 & 142,089 & - & - & 28 & - & - & - & - \\
\hline 印度 & - & - & - & - & - & - & - & - \\
\hline 海峽殖民地 & - & - & - & - & - & - & - & - \\
\hline 關領印度 & - & - & - & - & - & - & - & - \\
\hline 佛領印度 & - & - & - & - & - & - & - & - \\
\hline 比律䆩諸島 & - & - & - & - & - & - & - & - \\
\hline 英吉 利 & 236,175 & 107 & 6,408 & 978 & 7 & 1,495 & - & - \\
\hline 佛 蘭 西 & 7,629 & - & - & 907 & 3,565 & 1 & - & - \\
\hline 獨逸 & 39,400 & - & $43, \mathbf{3 3 3}$ & 30 & 1,669 & - & - & - \\
\hline 白耳笔 & 1,764 & - & - & - & - & 2,000 & - & - \\
\hline 伊 太利 & - & - & - & $\mathbf{2}$ & - & - & - & - \\
\hline 墺 太 利 & 6,396 & - & - & - & - & - & - & - \\
\hline $\begin{array}{l}\text { チェッュス } \\
\text { ロヴアキャ }\end{array}$ & - & - & - & -- & - & - & - & - \\
\hline 和＼cjkstart闌 & - & - & - & - & - & - & - & - \\
\hline 典 & 159 & - & 15,076 & - & - & - & 30 & - \\
\hline 諾 威 & - & - & - & - & - & - & - & - \\
\hline 露西亞 & - & - & - & - & - & - & - & - \\
\hline 西班牙 & - & - & - & - & - & - & - & - \\
\hline 丁 珠 & 6,877 & - & - & - & - & - & - & - \\
\hline 合 豙 國 & 117,771 & - & - & 82,038 & 6,189 & 3,455 & - & 40 \\
\hline 加奈陀 & - & - & - & - & - & - & - & - \\
\hline 伯刺西爾 & - & - & - & - & - & - & - & - \\
\hline 埃夜 & - & - & - & - & - & - & - & - \\
\hline 璒太刺利 & - & - & - & - & - & - & - & - \\
\hline 其 他 & - & - & - & - & - & - & - & - \\
\hline 計 & 561,156 & 107 & 64,817 & 84,338 & $\lfloor 1,462$ & 6,951 & 30 & 40 \\
\hline
\end{tabular}




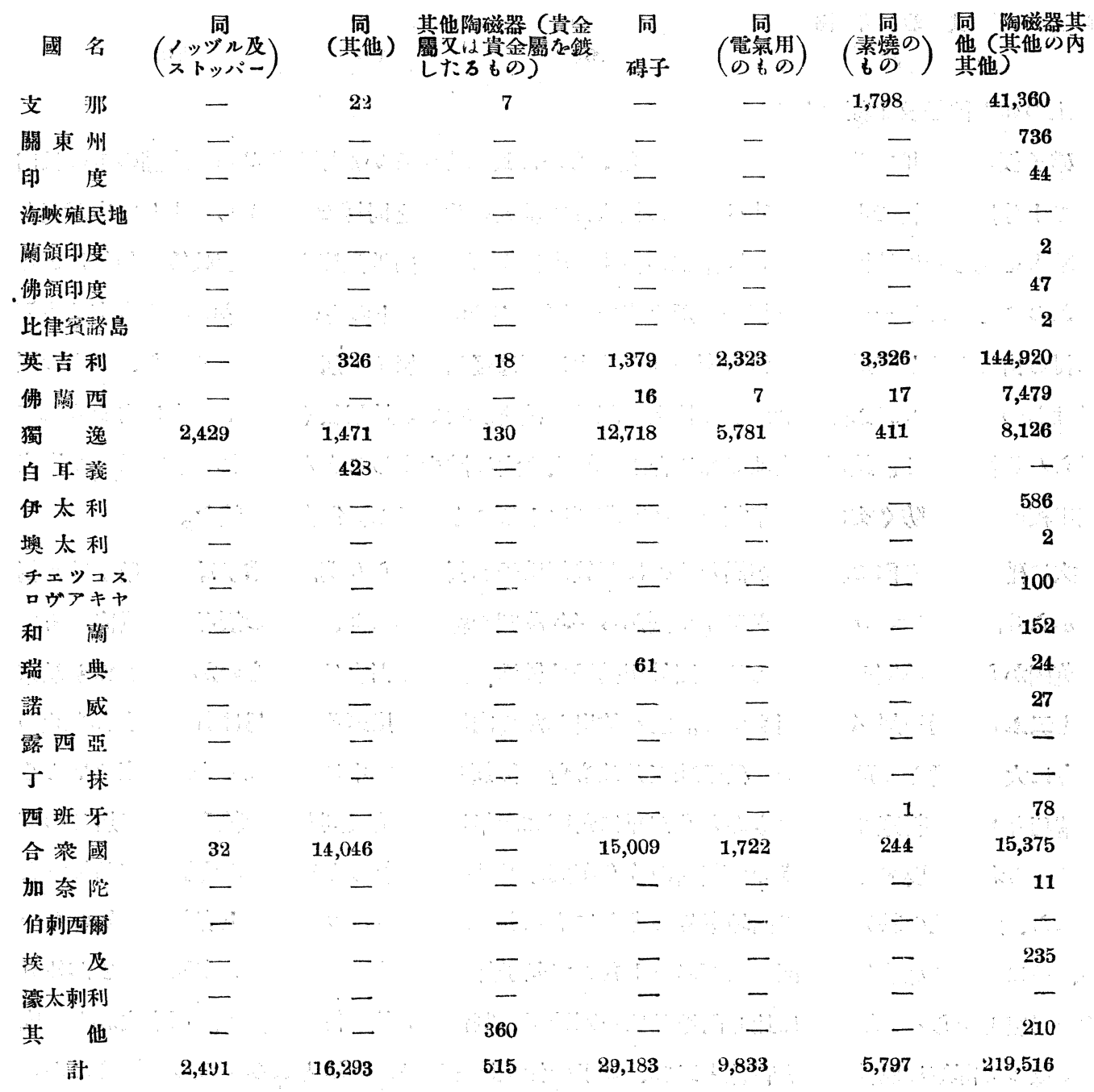

第六表 ヒメント輸入額 (單位千国)

成名 北米合䋰國 其他諸國 計

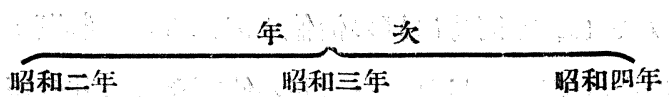

$\begin{array}{rr}318 & 923 \\ 11 & 19 \\ 2 & 2 \\ 331 & 944\end{array}$

598

第七表 人造丝石輸入額 (單位千圓)

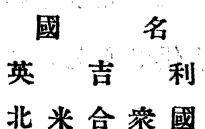

英吉利

北米合衂國

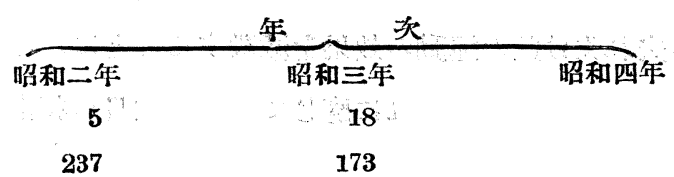




\section{其 他 诏國}

咕
9

251
197

212

以上の如き種類及金額である。

硝子板の內及地で生產することの出來ないものは致し方がをいが厚さ $2.2 \mathrm{~nm}$ 未滿のものは內

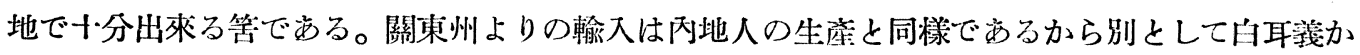
ら輸入を見るのは遺憾である。同菜誌の報和る處によると、內地生產者の販賣政策の如们による とかのととで饬る一つ快腕を振つて頂き度い。厚さ $2.2 \mathrm{~mm}$ 以上のものでも $5 \mathrm{~mm}$ 程度迄は生產 し得る由で方るし鐵道省其の他官廳方面では大に國兴愛用に努めて居る際であるから、多少の困 難は汤つても斯う云ふ際に製造して技衙の訓練を積まれたい。鏡用板も旭社では大に力を入れて 居られる樣である。鏡用が內地で間に合ふと輸入は大に減少することと思はれる。差當り輸出问 鏡用板の輸入を防ぐ文けでも年額 50〜60 澫圆に上るととと思ふ。御舊鬪を望む。

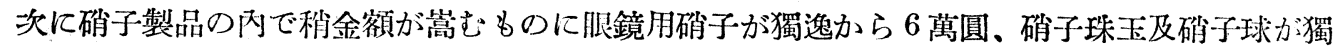
逸から 8 萬圓、チエッコスローヴアキヤ國から 4.3 萬圓の輸入があり、各種の製品郎雜貨问のもの が英國から 7.6 萬圆の輸入が市る。眼鏡用硝子は製造が困難で引合はないものかも知れぬが舶來 品上云ふと普通一組 4〜5圆も方る。之れ位出してら內地でも出桃そうに思はれる。之れも此の 機會に大に精進して頂き度い。硝子珠玉及球も色《種類も伍つて中には內地で未だ出來ないよう な精巧なものや新意匠のものも汤ららが鬼に角昭和四年には 7.7 萬圓からの輸入をして居るので あるから考究を要する。雜貨では英國の 76 萬圓などは高級な新らしい意匠の食器裝飾品等であ るから、之れ位の輸入は却て內地業界の參考にもなり、刺戟にも索り、開發上有效か子知れない が、茲に奇異に感ずるのは例へばデパートなどで切子鉢の如きもの是ると、意匠及大さが外見 的の對照とせられ、輸入品に比し內地品は一割乃至二割位安い札が付いて居る。而多之れを一度 手に取つて詳細に點檢すると昔色と云ひ、切子の仕上げと云ひ、素地と云ひ可なりの開きのある のが見受けられる。20〜30 圓又は夫れ以上の商品を買ふ人は之等の點に就て詳細に見た上でなけ れば買はないし、亦同時に葚の價值と云ふものを制別する丈けの見識を持つて居るものと解して よい。斯かる立場から見れば一二割の值開きでは其の短所を補ふに足らずして必ずや不滿を懷く に相望ない。ての心情はやがて同じ買ふなら良い方を郎輸大品を買ふてとになるのである。輸入 の切子硝子には高い關稅を賦課せられ運貨、手數料等を支拂ふと可なり經費が高まるのである。 この點から考へると同程度の品位のものでも今少し完全に賣り出されてもよい樣に思はれる。郎 內地品は輸入品に對して割高になると云ふ事になる。斯くて将折角官民協力して國㡾品の愛用に 努めても夫れ丈け此の運動の效果を減殺するてとになる。國民が競つて國崖品愛用の運動をする 誠意に對し、供給者は叉之れに應じて品質本位且つ相當價值のものを提供せらるることてそ當然 の道ではあるまいか。 
次に粘土製品の部であるが稍緾まつたものはタイル類である。郎獨逸 4.5 萬圆、合笔國 9 萬 圓、各種製品郎工藝品や高級玩具品で英國から 14.5 萬圓、支那から 4.1 萬圓の輸入がある。タ イル類の如きは設計者の新味を競ふ傾きと需要者の趣味による處多きが雼めに、强ひる事は出來 難いが、內地品で十分間に合ふと思ふ。設計家も一つ內地の陶箘者と十分接涉して然る上不滿足 ならば外國人注文を出すようにして独ひたい。岩崎家がE萬の財を投じて新築された建物でさへ 內地品を使用せられて居る。其の雅量は誠に敬服に堪へぬ。或る牛官の大銀行の新築などテラコ ッタ丈けで 10 萬圓からの差（輸入品 40 萬圓との事）があるにも拘らず、輸入品を指定したな ぞと云ふ話がある、一考を要すべきととと思ふ。英國からの 14.5 萬圓には各種の工藝品がある

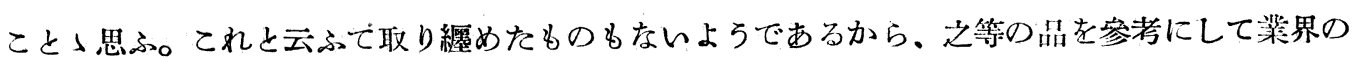
新味を出し以て輸入に償を付けて頂き度い。特に茶褐色の土瓶をどは年々相當の輸入があるよう であるが、內地ならば高濱附近の粘土で一寸工夫すれば隨分安く出來、逆に輸出も可能のてとと 思はれる。支那から輸入せらるるものには植木鉢や火鉢や水鉢等がある。又近頃支删料理が流行 するので食器類も相當輸大せらるるようである。食器以外のものは信樂、品野、常滑等の製品で 代用せらるるものが多い。

耐火煉瓦は昭和三年には 106 萬圓から輸入があつた。多分硝子槽空に用ひられたものと思ふ。 四年には本減して 56 萬圓となつた。之等は適當な原料が內地にない上云ふてとも輸入を見る原 因と思はれるから致し方がをいと云はば夫れまでであるが、特に斯の種のもの孝使用せらるる工 場は大工場であるから出桃ることなら原料で輸入せられて加工せられん事を希敁する。

人造砥石は近時著しく發達して輸入品に少らぬものが出來るよ5になつた。斯の種のものは使 用者が科學的に各種の試驗をして比較をして呂れるので、全く品質本位で製造すればよい。更に 進んで製紙パルプを作るに用ふる天然石に代るものを目下試驗中で相當の好成續繁げつ〉ある よらである。天然石は輸入品であるから此研究は誠に結棈なととで切に其の成功孛析る次第であ る。

要するに外觀を主として居る郎觀賞的なものには、販鿓方法の巧拙で隨分下らないものが輸入 せられ、值者高くすればする程信用が高まると云ふようなものもあり、製造家の努力に添はない ものもあるが具體的の試驗をして貝はれるのは、製造家の努力次第で成績の擧るのは誠に幸なて とである。觀賞的なものも一般需要者の觀識眼の向上するにつれ輸入の防遏も出來れば逆に輸出 の促進にもなる。近頃國產品愛用の運動に乘じ不良品の賈別きに好機を得たかの行をする不心得 者の出て來るてとは遺憾である。希くは眞に外國品に劣らざる品質のもの老可及的安價に提倛し 以て國產品愛用者に報ひられんてと冠） 